\title{
Pengaruh Metode Thawing Terhadap Kualitas Fisik dan Kimia Daging Sapi Beku
}

\author{
Dian Ari Prehatini', Sri Widya Lestari ${ }^{1}$, Dyah Triasih ${ }^{2 *}$ \\ ${ }^{1}$ Fakuktas Pertanian, Universitas Sebelas Maret \\ Jl. Ir Sutami No.36A, Jebres, Kec. Jebres, Kota Surakarta, Jawa Tengah 57126. \\ ${ }^{2}$ Program Studi Teknologi Pengolahan Hasil Ternak, Politeknik Negeri Banyuwangi \\ Jl. Raya Jember Km. 13 Labanasem Kabat, Banyuwangi \\ *Email korespondensi: triasihdyah@gmail.com
}

(Diterima: 21-08-2019; Disetujui:14-12-2019)

\begin{abstract}
ABSTRAK
Tujuan penelitian ini untuk mengetahui metode thawing yang terbaik dalam proses penyegaran kembali daging beku, ditinjau dari kualitas fisik dan kimia daging sapi beku. Materi yang digunakan adalah daging sapi beku bagian LD (Longissimus dorsi) yang telah disimpan dalam freezer bersuhu $-19^{\circ} \mathrm{C}$ selama lebih dari 12 bulan. Penelitian ini menggunakan Rancangan Acak Lengkap (RAL). Perlakuan yang diberikan adalah metode thawing $\mathrm{P}_{1}$ (refrigerator $3-5^{\circ} \mathrm{C}$ ), $\mathrm{P}_{2}$ (ruangan terbuka $27^{\circ} \mathrm{C}$ ), $\mathrm{P}_{3}$ (air mengalir $25^{\circ} \mathrm{C}$ ), dan $\mathrm{P}_{4}$ (waterbath $30-40^{\circ} \mathrm{C}$ ). Hasil analisis statistik menunjukan bahwa perbedaan metode thawing berpengaruh $(\mathrm{P}<0,05)$ terhadap kualitas fisik dan kimia. Metode thawing yang paling baik karena memberikan pengaruh kerusakan fisik yang paling sedikit adalah metode thawing dengan udara ruang karena mempunyai keempukan yang paling empuk dibandingkan metode thawing lainnya. Sedangkan metode thawing yang paling baik karena pemberikan pengaruh kerusakan kimia paling sedikit adalah metode thawing dengan udara dingin karena dapat mempertahankan kadar protein dalam daging dan memiliki kadar air yang rendah.
\end{abstract}

Kata kunci: daging beku, kualitas fisik, kualitas kimia, suhu, thawing

\begin{abstract}
The purpose of this study was to determine the best thawing method in the process of refreshing frozen meat, in terms of the physical and chemical quality of frozen beef. The material used is LD frozen beef (Longissimus dorsi) which has been stored in a freezer temperature of $-19^{\circ} \mathrm{C}$ for more than 12 months. This study uses a completely randomized design (CRD). The treatments given are the thawing method $\mathrm{P}_{1}$ (3-5 $5^{\circ} \mathrm{C}$ refrigerator), $\mathrm{P}_{2}\left(27^{\circ} \mathrm{C}\right.$ open space), $\mathrm{P}_{3}\left(25^{\circ} \mathrm{C}\right.$ running water), and $\mathrm{P}_{4}\left(30-40^{\circ} \mathrm{C}\right.$ water bath). The results of statistical analysis showed that the difference in the thawing method affected $(\mathrm{P}<0.05)$ on physical and chemical quality. The best thawing method because it provides the least physical damage effect is the thawing method with room air because it has the softest tenderness compared to other thawing methods. While the best thawing method is because the least effect of chemical damage is the cold air thawing method because it can maintain the protein content in meat and has a low water content.
\end{abstract}

Keywords: frozen meat, chemical quality, physical quality, temperature, thawing

\section{PENDAHULUAN}

Pembekuan adalah penyimpanan beku pada suhu $-12^{\circ} \mathrm{C}$ sampai $-24^{\circ} \mathrm{C}$ (Muchtadi \& Ayustaningwarno, 2010). Menurut Diana et al. (2018), proses pembekuan daging tidak akan merubah kualitas daging, namun kualitas daging akan berubah pada saat thawing. Perubahan kualitas daging beku minimal pada temperatur $-18^{\circ} \mathrm{C}$. Hampir seluruh air pada daging membeku pada temperature $-18^{\circ} \mathrm{C}$. Penyimpanan beku pada temperatur dibawah $-10^{\circ} \mathrm{C}$ akan meng-hambat pertumbuhan mikroorganisme pembusuk. Lama waktu penyimpanan mempengaruhi kualitas daging beku. Pada temperatur $-18^{\circ} \mathrm{C}$ daging beku mulai menunjukkan perubahan kualitas setelah penyimpanan selama 4-6 bulan (Soeparno, 2009). 
Thawing merupakan kelanjutan dari proses freezing. Thawing akan mengembali-kan bahan baku ataupun produk dari yang semula berbentuk fase padat menjadi fase cair. Berbagai kerusakan dapat terjadi pada makanan selama proses pembekuan maupun thawing secara lambat. Proses penyegaran kembali pada daging beku sebelum diolah atau diproses lebih lanjut, berperan dalam menentukan tingkat kerusakan fisik dan kimia daging, yang kemudian akan berpengaruh terhadap kualitas daging. Kualitas daging yang baik akan menghasilkan produk yang baik demikian pula sebaliknya.

Penelitian ini dilakukan untuk mengetahui pengaruh berbagai metode thawing daging beku sehingga didapat metode thawing terbaik terhadap kualitas fisik yang meliputi $\mathrm{pH}$, keempukkan, susut masak, dan DIA serta kualitas kimia meliputi kadar air, kadar abu, kadar protein, dan kadar lemak.

\section{MATERI DAN METODE}

Penelitian ini menggunakan daging sapi beku yang telah dibekukan selama lebih dari 12 bulan dan disimpan dalam freezer pada suhu $19^{\circ} \mathrm{C}$. Sebelum daging dipotong, alat-alat disterilkan terlebih dahulu menggunakan alkohol $70 \%$. Sampel dipotong sebanyak 20 sampel dengan ukuran 50 gram untuk uji kimia dan 200 gram untuk uji fisik. Kemudian dibungkus dengan plasik PP (polypropilen).

\section{Desain Penelitian}

Desain penelitian yang digunakan adalah Rancangan Acak Lengkap (RAL) pola searah dengan empat macam perlakuan. Setiap perlakuan terdiri dari lima ulangan. Perlakuan metode thawing pada $\mathrm{P}_{1}$ thawing dilakukan dalam refrigerator dengan suhu $3-5^{\circ} \mathrm{C}, \mathrm{P}_{2}$ thawing dilakukan dalam suhu ruang dengan suhu $27^{\circ} \mathrm{C}, \mathrm{P}_{3}$ dilakukan dengan menggunakan air mengalir pada suhu $25^{\circ} \mathrm{C}$, dan $\mathrm{P}_{4}$ thawing dengan menggunakan waterbath suhu $30-40^{\circ} \mathrm{C}$

\section{Pelaksanaan Penelitian}

Penelitian ini terdari dua tahap penelitian, yaitu persiapan sampel dan perlakuan thawing. Pada persiapan sampel, sampel diperoleh berasal dari otot Longissimus Dorsi (LD) sapi simental peranakan ongole jantan. Sampel dibuat dengan berat 50 gram dan 75 gram sebanyak 20 buah. Kemudian dibungkus dengan plastik polypropilen, 20 sampel tersebut dibagi menjadi empat kelompok dengan metode thawing yang berbeda. Tahap perlakuannya yaitu dengan memberikan perlakuan pada setiap daging yang telah dikelompokan dengan perlakuan sebagai berikut: $\mathrm{P}_{1}$ (thawing dalam refrigerator suhu diatur pada suhu $3-5^{\circ} \mathrm{C}$ ). $\mathrm{P}_{2}$ (thawing dengan didiamkan dalam suhu ruang $27^{\circ} \mathrm{C}$ ), $\mathrm{P}_{3}$ (thawing dengan air mengalir $25^{\circ} \mathrm{C}$ ), $\mathrm{P}_{4}$ (thawing dengan waterbath $40^{\circ} \mathrm{C}$ ). Daging di-thawing sampai menunjukan daging dalam kondisi segar, jika ditekan tidak keras (kenyal) dan suhu daging tidak terlalu dingin. Setelah daging menjadi segar selanjutnya dimasukan dalam coolbox, kemudian dibawa ke laboratorium untuk dianalisis kulitas fisik dan kimia.

\section{Analisis Data}

Data yang diperoleh dalam penelitian ini dianalisis dengan menggunakan analisis variansi berdasarkan Rancangan Acak Lengkap (RAL) pola searah untuk mengetahui adanya pengaruh perlakuan terhadap peubah yang diamati. Apabila hasil analisis data menunjukkan rata-rata perlakuan berbeda maka dilanjutkan dengan uji beda antar mean yaitu Duncan Multiple Range Test (DMRT) untuk mengetahui pebedaan antara 4 perlakuan. Pengolahan data menggunakan SAS 9.1 for Windows 2003 (Steel \& Torrie, 1995).

\section{HASIL DAN PEMBAHASAN}

\section{Kualitas Fisik Daging Sapi Beku}

Berdasarkan hasil analisis data kualitas fisik daging maka didapatkan Tabel 1 yang menunjukkan kualitas fisik daging beku.

Tabel 1. Uji kualitas fisik dari berbagai metode thawing

\begin{tabular}{lcccc}
\hline \multirow{2}{*}{ Parameter } & \multicolumn{5}{c}{ Metode Thawing } \\
\cline { 2 - 5 } & $\mathrm{P}_{1}$ & $\mathrm{P}_{2}$ & $\mathrm{P}_{3}$ & $\mathrm{P}_{4}$ \\
\hline $\mathrm{pH}$ & $6,86^{\mathrm{a}}$ & $6,72^{\mathrm{b}}$ & $6,8^{\mathrm{a}}$ & $6,7^{\mathrm{b}}$ \\
Susut masak (\%) & $34,67^{\mathrm{a}}$ & $31,80^{\mathrm{b}}$ & $30,30^{\mathrm{b}}$ & $32,50^{\mathrm{ab}}$ \\
Daya ikat air (\%) & $10,13^{\mathrm{a}}$ & $10,43^{\mathrm{a}}$ & $7,99^{\mathrm{a}}$ & $8,08^{\mathrm{a}}$ \\
Keempukan $\left(\mathrm{kg} / \mathrm{cm}^{2}\right)$ & $6,55^{\mathrm{b}}$ & $5,97^{\mathrm{b}}$ & $6,11^{\mathrm{b}}$ & $7,83^{\mathrm{a}}$ \\
\hline
\end{tabular}

Keterangan: ${ }^{\mathrm{ab}}$ superskrip yang berada pada baris yang sama menunjukkan perbedaan nyata $(\mathrm{P}<0,05)$ 


\section{pH}

Hasil penelitian menunjukkan bahwa ratarata presentase nilai $\mathrm{pH}$ tertinggi adalah thawing dalam udara dingin $\left(\mathrm{P}_{1}\right)$ yaitu sebesar 6,86, sedangkan presentase $\mathrm{pH}$ terendah adalah thawing dengan air hangat $\left(\mathrm{P}_{4}\right)$ yaitu 6,7. Metode thawing dengan udara ruang $\left(\mathrm{P}_{2}\right)$ dan air mengalir $\left(\mathrm{P}_{4}\right)$ masing-masing 6,72 dan 6,8. Laju thawing yang semakin lama tidak selalu diikuti dengan kenaikan $\mathrm{pH}$. Thawing dalam udara dingin suhu $3-5^{\circ} \mathrm{C}$ berlangsung 6 jam 54 menit menunjukkan $\mathrm{pH}$ yang paling tinggi di banding metode thawing lainnya. Thawing pada udara ruang dengan suhu 27-30 ${ }^{\circ} \mathrm{C}$ berlangsung selama 2 jam 6 menit dan thawing dengan air mengalir pada suhu $25-27^{\circ} \mathrm{C}$ berlangsung selama 29 menit. Sedangkan thawing dengan air hangat pada suhu $40-50^{\circ} \mathrm{C}$ yang berlangsung selama 19 menit menunjukkan $\mathrm{pH}$ yang paling rendah, ini berarti semakin lama waktu thawing maka $\mathrm{pH}$ akan semakin meningkat. Hasil penelitian menunjukkan ratarata $\mathrm{pH}$ yang lebih tinggi daripada hasil penelitian Soeparno (2009) pH daging normal setelah posmortem berkisar antara 5,4-5,6. Hal ini menunjukkan bahwa daging yang mengalami proses penyimpanan mempunyai $\mathrm{pH}$ yang lebih tinggi daripada daging segar. Menurut Diana et al. (2018), bahwa $\mathrm{pH}$ berpengaruh terhadap kualitas daging. Tinggi rendahnya $\mathrm{pH}$ dipengaruhi oleh proses metabolisme bakteri dalam menghasilkan asam. Air ini salah satu penyebab bakteri yang ada dalam daging sangat mudah tumbuh.

\section{Susut Masak}

Hasil penelitian didapat nilai susut masak berurutan dari yang tertinggi yaitu dengan thawing udara dingin $\left(\mathrm{P}_{1}\right)$ 34,67\%, thawing dengan air hangat $\left(\mathrm{P}_{3}\right) 32,50 \%$, thawing dengan udara ruang $\left(\mathrm{P}_{2}\right) 31,80 \%$, dan thawing dengan air mengalir $\left(\mathrm{P}_{4}\right)$ 30,30\%. Rata-rata presentase susut masak tiap metode thawing dalam batas normal. Sesuai dengan pendapat Utami et al. (2006), bahwa nilai susut masak antara $1,5 \%$ sampai $54,5 \%$ dengan kisaran 15 sampai 40\%. Nilai susut masak yang tinggi ini dikarenakan selama penyimpanan beku terjadi perubahan-perubahan protein otot, yang menyebabkan berkurangnya nilai daya ikat air protein otot dan meningkatnya jumlah cairan yang keluar (drip) dari daging akibat dari pembekuan dan penyimapan beku daging (Jamhari, 2000).

\section{Daya Ikat Air}

Hasil penelitian menunjukkan daya ikat air tertinggi adalah thawing dengan udara ruang $\left(\mathrm{P}_{2}\right)$ $10,43 \%$, selanjutnya thawing dengan udara dingin $\left(\mathrm{P}_{1}\right)$ 10,13\% dan thawing dengan air hangat $\left(\mathrm{P}_{4}\right)$ $8,08 \%$, dan yang paling rendah adalah thawing dengan air mengalir $\left(\mathrm{P}_{3}\right)$ yaitu $7,99 \%$. Menurut Risnajati (2010), daya ikat air dipengaruhi oleh laju dan besarnya nilai $\mathrm{pH}$. Semakin tinggi $\mathrm{pH}$ maka semakin tinggi pula prosentase daya ikat air. Menurut Lawrie (2003), Daya ikat air dipengaruhi oleh $\mathrm{pH}, \mathrm{pH}$ semakin tinggi semakin sedikit air penurunan daya ikat air.

\section{Keempukan}

Hasil penelitian menunjukkan nilai keempukan diurutkan dari yang paling tinggi adalah dengan metode thawing dengan air hangat $\left(\mathrm{P}_{4}\right)$ yaitu 7,83 , metode thawing dengan udara dingin $\left(\mathrm{P}_{1}\right) 6,55$, thawing dengan air mengalir $\left(\mathrm{P}_{3}\right)$ 6,11, dan thawing dengan udara ruang $\left(\mathrm{P}_{2}\right)$ 5,97. Menurut Aberle et al. (2001), menyatakan bahwa Keempukan pada daging dipengaruhi oleh struktur miofibril dan status kontraksi, jumlah jaringan ikat, dan daya ikat air pada daging. Menurut Soeparno (2009), bahwa perbedaan jumlah jaringan ikat, lokasi otot, umur, dan jenis kelamin dapat mempengaruhi keempukan daging. Menurut hasil penelitian Jamhari (2000), bahwa penyimpanan beku dapat menurunkan nilai daya putus atau meningkatkan keempukan daging secara nyata. Hal ini disebabkan karena selama penyimpanan beku terjadi kerusakan proteinprotein daging.

\section{Kualitas Kimia Daging Sapi Beku}

Berdasarkan hasil analisis data kualitas kimia daging maka didapatkan Tabel 2 yang menunjukkan kualitas kimia daging beku.

Tabel 2. Uji Kualitas Kimia dari Berbagai Metode Thawing

\begin{tabular}{lcccc}
\hline \multirow{2}{*}{ Parameter } & \multicolumn{4}{c}{ Metode Thawing } \\
\cline { 2 - 4 } & P1 & P2 & P3 & $74.26^{\mathrm{a}}$ \\
\hline Kadar Air & $71.05^{\mathrm{ab}}$ & $68.61^{\mathrm{b}}$ & $73.64^{\mathrm{a}}$ & $1.73^{\mathrm{a}}$ \\
Kadar Abu & $1.71^{\mathrm{a}}$ & $1.50^{\mathrm{a}}$ & $1.76^{\mathrm{a}}$ & $20.58^{\mathrm{c}}$ \\
Kadar Protein & $24.96^{\mathrm{a}}$ & $24.08^{\mathrm{ab}}$ & $22.13^{\mathrm{bc}}$ & 2.14 \\
Kadar Lemak & 3.32 & 3.75 & 2.13 & \\
\hline
\end{tabular}

Keterangan: abc superskrip yang berbeda pada baris yang sama menunjukkan perbedaan nyata $(\mathrm{P}<0,05)$ 


\section{Kadar Air}

Perlakuan metode thawing berpengaruh terhadap kadar air daging $(\mathrm{P}<0,05)$ ditunjukan pada Tabel 2. Daging yang di-thawing dengan suhu hangat (waterbath $40^{\circ} \mathrm{C}$ ) memiliki kadar air yang tertinggi dibandingkan dengan perlakuan metode thawing yang lain. Diduga terjadi pengikatan air oleh protein pengikat air khususnya myosin selama peningkatan suhu thawing. Menurut Sari (2019), Menurunnya kadar air pada proses thawing karena terjadinya degradadi protein miofibril (aktin dan miosin) sehingga air tidak dapat mengikat air dan melemahkan sistem ikatan hidrogen dan menghasilkan disintegrasi struktur tiga dimensi protein, akibatnya terjadi penggabungan protein.

\section{Kadar Abu}

Perlakuan metode thawing tidak berpengaruh terhadap kadar abu daging (Tabel 2). Kadar abu terendah pada perlakuan thawing pada suhu ruang $\left(\mathrm{P}_{2}\right)$ dibandingkan dengan perlakuan pada air mengalir $\left(\mathrm{P}_{3}\right)$. Widati (2008), menyatakan bahwa kadar abu daging beku sekitar 0,41\%. Sedangkan pada penelitian ini menghasilkan kadar abu yang lebih rendah. Hal ini diduga karena terjadi kehilangan sejumlah mineral pada saat thawing, sehingga eksudat yang keluar banyak terkandung mineral yang larut dalam air maupun lemak yang ikut teroksidaasi.

\section{Kadar Protein}

Perlakuan metode thawing berpengaruh terhadap kadar protein daging $(\mathrm{P}<0,05)$ ditunjukan pada Tabel 2. Kadar protein terendah diperoleh pada metode thawing dengan water bath $40^{\circ} \mathrm{C}$. Menurut Utami et al. (2006), selama penyimpanan beku, daging akan mengalami kerusakan yang bersifat irreversible. Kerusakan pada jaringan yang telah mengalami pembekuan dapat diperburuk selama proses penyegaran kembali (thawing). Selama proses thawing berlangsung, pengerutan serabut otot akan memaksa sejumlah cairan untuk keluar. Widati (2008), menyatakan bahwa denaturasi protein tidak ada pengaruhnya dengan jumlah asam amino namun hanya mempengaruhi kualitas secara fisik daging . Kadar protein daging yang disimpan lebih dari 12 bulan dan dengan empat metode thawing yang dilakukan pada penelitian ini masih berada pada kisaran normal. Menurut Brahmantiyo (2000), bahwa kandungan protein daging sapi sebesar $16,7 \%$ sampai $30 \%$.

\section{Kadar Lemak}

Perlakuan metode thawing tidak berpengaruh terhadap kadar lemak daging $(\mathrm{P}>0,05)$ ditunjukan pada Tabel 1. Perlakuan thawing pada suhu air mengalir (P3) memiliki kadar lemak yang lebih rendah dibandingkan dengan kadar lemak yang diperoleh dengan perlakuan thawing pada suhu ruang (P2). Hal ini diduga pada saat pencairan daging beku pada air mengalir lemak daging mengalami oksidasi, dan daging mendapat tekanan dari air yang mengalir sehingga membuat daging mengeluarkan eksudat yang mengandung lemak akibat reaksi yang ditimbulkan dari tekanan air yang mengalir dibandingkan dengan daging yang didiamkan pada suhu ruang. Guiroy et al. (2000), bahwa rata-rata kadar lemak rendah dengan kadar lemak intramuskuler daging 5\%. Hai ini diduga akibat lamanya proses pembekuan dan suhu beku. Menurut Astuti (2012), pembekuan daging tidak berpengaruh terhadap kadar lemak dan memiliki korelasi negatif dengan kadar air. semakin tinggi kadar lemak maka kadar airnya semakin rendah. Selain itu Enzim lipase dapat aktif pada suhu rendah dan beku karena mempunyai energi aktifitas yang rendah.

\section{KESIMPULAN}

Metode thawing dengan refrigerator pada suhu $3-5^{\circ} \mathrm{C}$ dapat mempertahankan kadar protein pada kondisi stabil. Metode thawing dengan udara luar lebih efektif karena mempunyai daging yang lebih empuk dibanding metode thawing lain. Kadar air terbesar dan $\mathrm{pH}$ terendah diperoleh pada daging yang dithawing dengan air hangat. Sedangkan metode thawing dengan air mengalir memberikan prosentase susut masak yang paling rendah daripada metode thawing lainnya.

\section{DAFTAR PUSTAKA}

Aberle, D.E., J.C. Forrest, D.E. Gerrard \& E.W. Mills. 2001. Principles of Meat Science. $4^{\text {th }}$ Edition. W. H. Freeman and Company, San Fransisco, United States of America.

Astuti, N. 2012. The effect of different frozen storage time on the chemical quality of beef. Jurnal Agrisains 3(4):13-19.

Brahmantiyo, B., 2000. Sifat fisik dan kimia daging sapi brahman cross, angus. dan murray grey. Media Veteriner 7(2):9-11.

Diana, C., E, Dihansih, \& D. Kardaya. 2018. Kualitas fisik dan kimiawi daging sapi beku pada berbagai metode thawing. Jurnal Pertanian 2(2): 130-138. 
Guiroy, P. J., D.G. Fox., D.H. Beermann, \& D. J. Ketchen. 2000. Performance and meat quality of beef steers fed corn-based or bread. J Anim Sci 78:784-790.

Jamhari. 2000. Perubahan sifat fisik dan organoleptik daging sapi selama penyimpanan beku. Buletin Peternakan 24(1):43-50.

Lawrie, R.A. 2003. Ilmu Daging. Universitas Indonesia. Jakarta.

Muchtadi, T.R. \& F. Ayustaningwarno. 2010. Teknologi Proses Pengolahan Pangan. Alfabeta. Bogor.

Risnajati, D. 2010. Pengaruh lama penyimpanan dalam lemari es terhadap ph, daya ikat air, dan susut masak karkas broiler yang dikemas plastik polyethylen. Jurnal Ilmiah Ilmu-Ilmu Peternakan 8(6):309-315.
Sari, S.F. 2019. Pengaruh perbedaan metode pencairan (thawing) terhadap kualitas daging Abalon (Haliotis asinina) beku. Saintek Perikanan 14(2):106-109.

Soeparno. 2009. Ilmu Dan Teknologi Daging. Gadjah Mada University Press. Yogyakarta.

Steel, C.J. \& J.H. Torrie.1995. Prinsip dan Prosedur Statistik. PT. Gramedia. Jakarta.

Utami, U.R., Jamhari, \& Rusman. 2006. Pengaruh metode thawing terhadap kualitas fisik dan mikrostruktur daging beku sapi peranakan ongole jantan dewasa. Buletin Peternakan 30(3):143-153. 